\title{
THE POTENCY OF MUSCULOSKELETAL DISORDERS ERGONOMIC RISKS OF PHARMACY WORKER AT A HOSPITAL PHARMACY INSTALLATION IN BANDUNG
}

\author{
RIZKI SITI NURFITRIA*, ENTRIS SUTRISNO, SUCI RAMADHANIA
}

\author{
Department of Pharmacy, Clinical and Community Research Group, Sekolah Tinggi Farmasi Bandung, Jalan Soekarno Hatta 754 Cibiru \\ Bandung 40617, Indonesia. Email: rizki.sitinurfitria@stfb.ac.id
}

Received: 07 March 2018, Revised and Accepted: 25 March 2018

\section{ABSTRACT}

Objectives: The purpose of this study was to observe the potency of Musculosceletal Disorders (MSDs) ergonomic risks of pharmaceutical works in a hospital pharmacy including preparing, storage, distribution, using computer workstation and to provide preventive suggestion in order to increase safety and prevent decrease of productivity in the hospital pharmacy installation.

Methods: It was qualitative and quantitative descriptive research. Data were taken using observational method during pharmaceutical work from February to April 2017 and analyzed using Rapid Entire Body Assessment (REBA) worksheet to obtain the level of MSDs risk factors. The participants were categorized into low risk for score of $<4$, medium risk for score of 4-7, and high risk for score of 8-10. Data were showed in statistic and narrative explanation.

Results: $42.9 \%$ of workers were in high risk, $35.7 \%$ of workers were in medium risk, $14.3 \%$ of workers were in very high risk, and $7.1 \%$ of pharmaceutical workers in hospital pharmacy were in low risk.

Conclusion: Most of the workers had potency for MSDs. Common problems related to MSDs occurred were basic risk factors during pharmaceutical work such as force, repetition, awkward posture, static posture, and contact stress that caused trauma.

Keywords: Musculoskeletal disorders, Hospital pharmacy installation, Rapid entire body assessment, Pharmaceutical works.

(C) 2018 The Authors. Published by Innovare Academic Sciences Pvt Ltd. This is an open access article under the CC BY license (http://creativecommons. org/licenses/by/4. 0/) DOI: http://dx.doi.org/10.22159/ajpcr.2018.v11s1.26602

\section{INTRODUCTION}

Occupational health and safety (OHS) is a part of protection for the workforce and aims to prevent as well reduce accidents and occupational illness. Hospital as health-care facilities should give priority on quality service improvement to the community without ignoring the OHS for all hospital workers [1,2]. There were data and facts about OHS in hospital. According to the WHO data of 35 million health workers, three million people were exposed to blood pathogens (two million on HBV virus, 0.9 million on HBC virus, and 170,000 on HIV/AIDS virus). The results of a 1988 National Safety Council (NSC) report showed that $41 \%$ of hospital accidents were greater than workers in other industries with injection needle syringe injuries as the largest [1]. Therefore, based on Indonesian Health Law No. 36 year 2009 clause 165, "Workplace manager is required to make all efforts on health through prevention, improvement, treatment, and recovery for the workforce" [3]. Therefore, workplace manager at hospital has an obligation to protect the workforce. The hospital is prosecuted for implementing efforts on OHS thoroughly so that the occurrence of occupational diseases and work accident (KAK) risks at hospital can be avoided [4].

As with any other installations in hospital, there are risks from hazard exposure in the workplace environment including pharmacy installation. The occupational hazards, other than physical, biological, chemical, and psychosocial factors in pharmacy installation, also include ergonomic hazard risks, which is the result of non-conformity between workers with their way to work and their work environment. Currently ergonomic hazards and problems are not only felt by the workers at manufacture only but also real ergonomic problems can be found everywhere including the hospital pharmacy installation. The workers in hospital pharmacy installations include pharmacists, pharmacy assistants, and administrative personnel [3].

One of the ergonomic hazards that can be caused by non-conformity and the workers discomfort in doing the job is musculoskeletal disorders. Based on research conducted by Izzadirat, 79\% of adult workers complaint experienced MDS, especially low back pain [5].

Based on data from Bureau of Labor Statistics within the US department of labor in 2003, there were 867,766 cases of musculoskeletal disorders related to work, and based on research conducted by Biomedic and Pharmacy, Health Research and Development Agency, Indonesia Ministry of Health in 2006 regarding musculoskeletal pain complaints on industrial workers, 950 workers who had been studied about $52.8 \%$ of them had musculoskeletal complaints.

Based on research by Aminian et al., in 2012, 87.7\% of the pharmacy personnel were reported having a risk of musculoskeletal disorders [7]. The result of the research is identification of work posture on pharmacy installation worker in Madiun with REBA method got $25 \%$ of workers with REBA score 4-7 (medium risk), 25\% of workers with rapid upper limb assessment (RULA) score 1-2 (reasonable posture), 37.5\% of workers with RULA score 3-4 (medium risk), and $12.5 \%$ of workers with RULA score 5-6 (high risk). The most frequent musculoskeletal complaints were at the waist (87.5\%) [6]. The purpose of this study was to observe the potent of musculoskeletal disorders (MSDs) and risk factor of pharmacy workers in hospital pharmacy installation and to give prevention suggestion to increase safety in hospital pharmacy installation.

\section{METHODS}

This study was a descriptive qualitative and quantitative research to obtain the potential risk profile of MSDs on pharmacy installation personnel $(n=42)$. The types of activity at the hospital pharmacy include administration, clinical, and non-clinical pharmacy services. Clinical pharmacy services observed were prescription services including prescription assessment and dispensing of pharmaceutical preparations (i.e., compounding, putting drug etiquette and labels, and drug information service). Non-clinical pharmacy services observed were storage activities or more pharmaceutical preparation done by 
warehouse or service personnel. Data were taken using observational method during pharmaceutical works and analyzed using REBA worksheet to know the potential risk of MSDs [8]. Data are presented in the form narration and statistics.

\section{RESULTS}

Characteristics of the respondents are shown in Table 1. Pharmacy workers involved in the study were dominated by female from 17 to 35 years' old. The most widely performed activity was drug dispensing, administrative works, drug information, and drug management.

According to an Ergonomic Guide For Hospital Pharmacies issued by OHS assessment series (OHSAS) in 2004, there were risks of occurring MSDs on pharmaceutical works of hospital pharmacy including the use of computers and the process of preparing the drug. Reaching out and preparing the medication in an incorrect sitting or standing position can cause rigid posture of the neck and shoulders, closing and opening the medicine bottle or container can cause movement repetition of fingers and hands. Reaching the storage area drugs on a high rack can cause odd posture on the shoulder. Bending move while taking medication on the low shelf can cause odd posture on your back and shoulders. Arranging a stock can cause odd posture on the back, neck, and shoulders. Lifting a cardboard box containing drug supply needs great power use, and standing for a long time can cause disruption to the back and feet. Activity of pushing and pulling cart also raises risk of MSDs. Results on the observation and measurements with REBA worksheet from different activities are described in Table 2 .

\section{DISCUSSION}

There were four administrative personnels who have high risk level because it is in the range of a score of 8-10 and the other four have level of medium risk because it is in the range of a score of $4-7$. The example

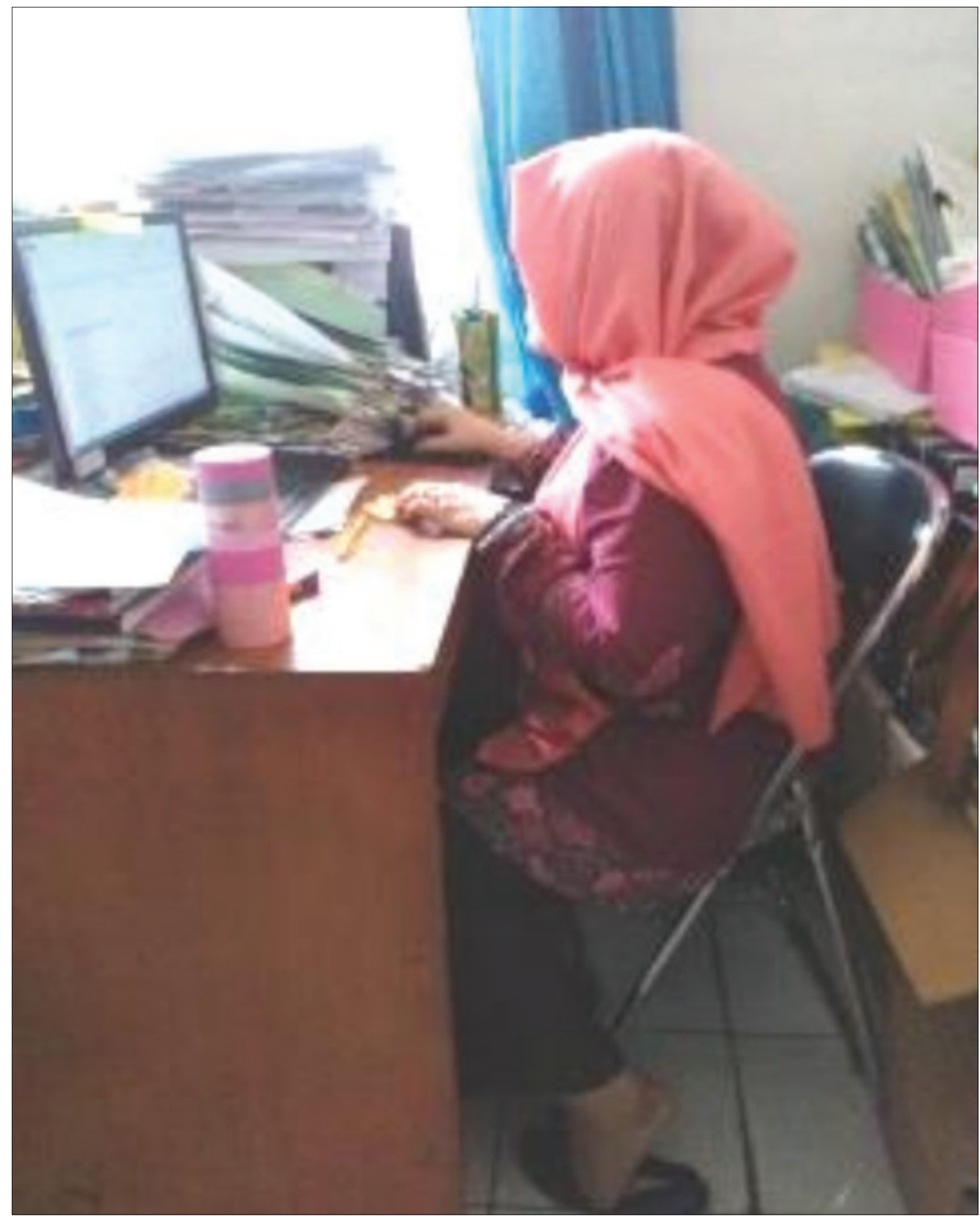

Fig. 1: Administrative work position which has a high risk 
of an administrative work position on the hospital pharmacy that have high risk can be seen on Fig. 1.

According to the workplace ergonomics reference guide $3^{\text {rd }}$ edition 2016, back position when working with computer must be supported by the seat backrest and be a static position because the personnel was in the back position without support for more of $20 \mathrm{~s}$ on observation, the position of the shoulder was not relaxed and raised shoulders making muscle work harder, and the foot position does not stand entirely on the floor or only certain parts that press can cause trauma to the part [9]. As correction, the workers have to adjust the seat so the flat

Table 1: Characteristics of respondents

\begin{tabular}{ll}
\hline Characteristics & Frequency (\%) \\
\hline Sex & \\
Male & $8(19)$ \\
Female & $34(81)$ \\
Activity administrative works & $8(19)$ \\
Prescription screening & $5(11.9)$ \\
Dispensing & $13(31)$ \\
Delivering drug information & $8(19)$ \\
Drug management & $8(19)$ \\
Age range & \\
17-25 & $16(38.10)$ \\
26-35 & $18(42.86)$ \\
36-45 & $6(14.28)$ \\
$46-55$ & $2(4.76)$ \\
Total & $42(100)$ \\
\hline
\end{tabular}

*Age classification based on Indonesia ministry of health 2009 [3]

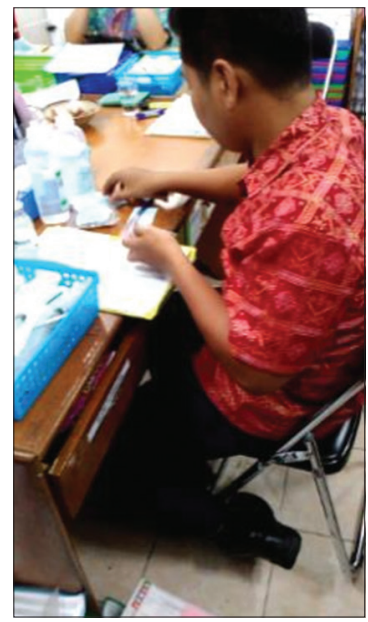

Fig. 2: Position of dispensing section which have a high risk feet is on the floor without pressure on the back or other foot section, adjust keyboard position slightly below the elbow, and set the monitor to reduce glare on the screen.

The working position of the dispensing section in the hospital pharmacy which has a high risk can be seen in the Fig. 2 below.

According to an ergonomic guide for hospital pharmacies issued by OHSAS in 2004, standing position for dispensing is by paying attention to the height of the elbow and the work surface. Dispensing activities includes packaging, labeling and preparing extemporaneous compounding which was occurred very low (less than $5 \%$ in previous studies)[10]. In the compounding and packaging activities, work surface height is about $5-10 \mathrm{~cm}$ above high elbow while when giving etiquette and labeling is about $5-10 \mathrm{~cm}$ below the elbow height. On sitting position, chair used with a backrest should be chosen to be able to support the back, the soles of the feet stand entirely on the base, and knee barriers such as drawers or boards must be removed to avoid any trauma due to press on the knee [10]. Appropriate sitting position for dispensing activity can be seen in Fig. 3 .

Position of workers delivering drug information services which has a high risk can be seen in Fig. 4.

While delivering drug information, room comfort as well as position the body is very important to prevent muscle disorders. Absence of upper window barrier between patient and pharmacists can reduce the risk of odd posture on the neck and back. Placement of goods around the information area must be limited, such as the buildup of files that are not required for the activity. Fig. 5 is a reference drug information room with a good esthetic and convenient for both pharmaceutical personnel and patients during service.

It can be seen that the front desk enables unlimited wide reach and not limited by many objects. The absence of glass delimiters facilitates interaction and the delivery of drug information to the patient, either performing demonstration how to use drugs, explaining drug etiquette and labels or other information clearly to ensure that the patient will understand about the information. Pharmacists can also easily change the position of body to sit or stand for reducing the presence of static posture because moving spaces is not limited.

Position of pharmaceutical works during management activities (i.e., pharmaceutical preparations) that have very high risk can be seen in Fig. 6.

It appears that the activities of storage, retrieval, and transporting goods with inappropriate posture can lead to high risk. Taking goods on the low shelf with wrong position can cause odd posture on the neck, back, and legs. Stack objects obstruct the range work can cause emphasis on knee and pain to injury. Any kind of goods should not be placed in the

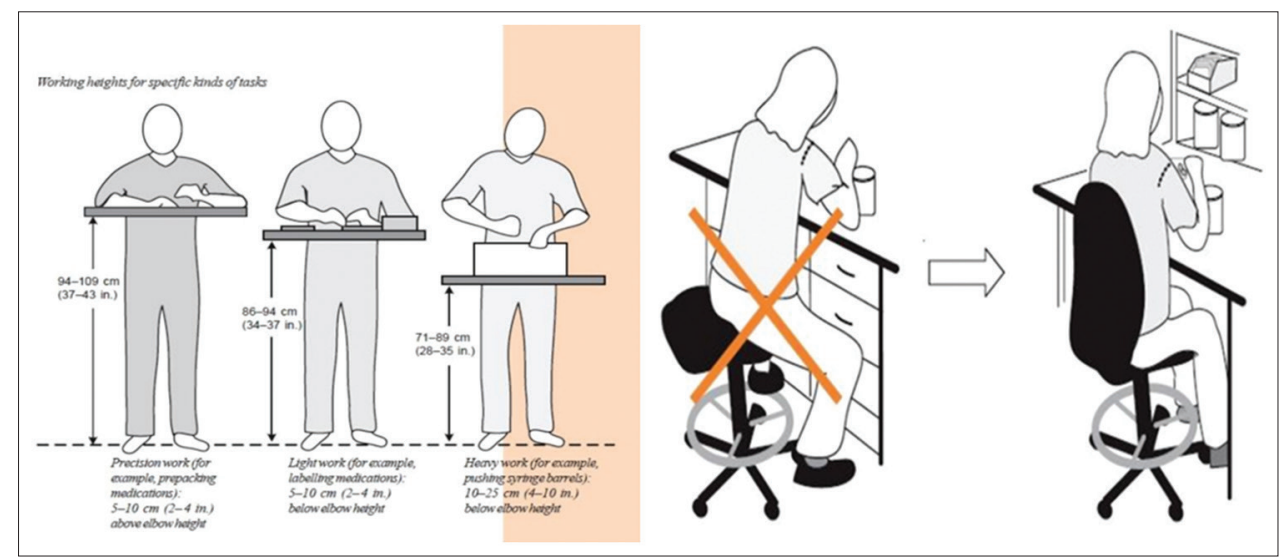

Fig. 3: Ideal position during dispensing [12] 
Table 2: Potential scoring results of musculoskeletal disorders occurrence using REBA worksheet

\begin{tabular}{|c|c|c|c|c|c|c|c|c|c|c|c|c|c|c|}
\hline \multirow{2}{*}{$\begin{array}{l}\text { Initial } \\
\text { name }\end{array}$} & \multirow[t]{2}{*}{ Sex } & \multirow[t]{2}{*}{ Age } & \multirow[t]{2}{*}{ Activity } & \multicolumn{9}{|c|}{ Measurement score } & \multirow{2}{*}{$\begin{array}{l}\text { REBA } \\
\text { score }\end{array}$} & \multirow[t]{2}{*}{ Risk } \\
\hline & & & & Neck & Trunk & Leg & A & $\begin{array}{l}\text { Upper } \\
\text { arm }\end{array}$ & $\begin{array}{l}\text { Lower } \\
\text { arm }\end{array}$ & Wrist & B & $\mathrm{C}$ & & \\
\hline EU & $\mathrm{P}$ & 29 & Administration & 2 & 2 & 4 & 6 & 2 & 2 & 2 & 3 & 6 & 7 & M \\
\hline MT & $\mathrm{P}$ & 21 & Administration & 2 & 2 & 4 & 6 & 1 & 2 & 2 & 2 & 6 & 8 & $\mathrm{H}$ \\
\hline NV & $\mathrm{P}$ & 23 & Administration & 2 & 2 & 4 & 6 & 2 & 2 & 1 & 2 & 6 & 8 & $\mathrm{H}$ \\
\hline $\mathrm{RN}$ & $\mathrm{P}$ & 19 & Administration & 2 & 1 & 4 & 4 & 2 & 2 & 1 & 2 & 4 & 6 & M \\
\hline LD & $\mathrm{P}$ & 21 & Administration & 3 & 1 & 4 & 6 & 2 & 2 & 1 & 2 & 6 & 7 & M \\
\hline TR & $\mathrm{P}$ & 24 & Administration & 2 & 2 & 4 & 6 & 1 & 2 & 1 & 1 & 6 & 8 & $\mathrm{H}$ \\
\hline YT & $\mathrm{P}$ & 46 & Administration & 2 & 2 & 4 & 6 & 2 & 2 & 2 & 3 & 5 & 6 & M \\
\hline $\mathrm{HN}$ & $\mathrm{P}$ & 26 & Dispensing & 2 & 2 & 4 & 6 & 1 & 2 & 2 & 3 & 6 & 7 & M \\
\hline FT & $\mathrm{P}$ & 35 & Dispensing & 2 & 2 & 1 & 3 & 2 & 2 & 2 & 4 & 2 & 3 & $\mathrm{~L}$ \\
\hline UM & $\mathrm{P}$ & 30 & Dispensing & 1 & 1 & 1 & 1 & 2 & 2 & 2 & 4 & 2 & 3 & $\mathrm{~L}$ \\
\hline $\mathrm{RF}$ & $\mathrm{L}$ & 26 & Dispensing & 2 & 3 & 4 & 7 & 1 & 2 & 1 & 2 & 7 & 8 & $\mathrm{H}$ \\
\hline IS & $\mathrm{P}$ & 32 & Dispensing & 2 & 3 & 4 & 6 & 2 & 2 & 3 & 5 & 8 & 9 & $\mathrm{H}$ \\
\hline MU & $\mathrm{P}$ & 24 & Dispensing & 3 & 3 & 3 & 8 & 2 & 2 & 3 & 5 & 10 & 11 & $\mathrm{VH}$ \\
\hline WI & $\mathrm{P}$ & 22 & Dispensing & 2 & 2 & 4 & 6 & 2 & 2 & 2 & 4 & 7 & 8 & $\mathrm{H}$ \\
\hline LI & $\mathrm{P}$ & 40 & Dispensing & 2 & 2 & 4 & 6 & 2 & 2 & 2 & 5 & 8 & 9 & $\mathrm{H}$ \\
\hline SA & $\mathrm{P}$ & 22 & Dispensing & 2 & 2 & 4 & 6 & 2 & 2 & 2 & 4 & 7 & 8 & $\mathrm{H}$ \\
\hline NO & $\mathrm{P}$ & 28 & Dispensing & 2 & 2 & 4 & 6 & 1 & 1 & 2 & 2 & 6 & 8 & $\mathrm{H}$ \\
\hline $\mathrm{TN}$ & $\mathrm{P}$ & 37 & Dispensing & 2 & 3 & 4 & 7 & 2 & 2 & 3 & 4 & 8 & 10 & $\mathrm{H}$ \\
\hline $\mathrm{TE}$ & $\mathrm{P}$ & 44 & Dispensing & 2 & 2 & 2 & 4 & 2 & 1 & 2 & 2 & 4 & 6 & M \\
\hline WJ & $\mathrm{P}$ & 30 & Drug information & 2 & 1 & 4 & 4 & 1 & 2 & 2 & 3 & 4 & 5 & M \\
\hline VN & $\mathrm{P}$ & 23 & Drug information & 2 & 1 & 1 & 2 & 1 & 1 & 2 & 2 & 2 & 4 & M \\
\hline LN & $\mathrm{P}$ & 28 & Drug information & 2 & 3 & 4 & 7 & 2 & 2 & 2 & 3 & 7 & 8 & $\mathrm{H}$ \\
\hline SN & $\mathrm{P}$ & 22 & Drug information & 1 & 2 & 4 & 5 & 3 & 2 & 2 & 5 & 6 & 7 & M \\
\hline DA & $\mathrm{P}$ & 24 & Drug information & 3 & 3 & 4 & 8 & 3 & 2 & 3 & 7 & 10 & 11 & VH \\
\hline NT & $\mathrm{P}$ & 28 & Drug information & 2 & 2 & 2 & 6 & 2 & 2 & 2 & 4 & 7 & 8 & $\mathrm{H}$ \\
\hline IR & $\mathrm{P}$ & 29 & Drug information & 2 & 2 & 4 & 6 & 2 & 2 & 2 & 3 & 6 & 7 & M \\
\hline YL & $\mathrm{P}$ & 29 & Drug information & 2 & 3 & 4 & 7 & 2 & 2 & 2 & 4 & 8 & 8 & $\mathrm{H}$ \\
\hline AS & $\mathrm{P}$ & 23 & Drug mngt & 1 & 2 & 1 & 3 & 2 & 1 & 3 & 5 & 4 & 5 & M \\
\hline RA & $\mathrm{P}$ & 29 & Drug mngt & 2 & 4 & 4 & 8 & 2 & 2 & 1 & 4 & 9 & 12 & $\mathrm{VH}$ \\
\hline $\mathrm{AG}$ & $\mathrm{L}$ & 28 & Drug mngt & 2 & 4 & 4 & 8 & 4 & 2 & 2 & 9 & 10 & 11 & VH \\
\hline UJ & $\mathrm{L}$ & 38 & Drug mngt & 1 & 2 & 3 & 6 & 2 & 2 & 2 & 4 & 7 & 8 & $\mathrm{H}$ \\
\hline HL & $\mathrm{P}$ & 24 & Drug mngt & 2 & 3 & 2 & 5 & 2 & 1 & 2 & 4 & 5 & 7 & M \\
\hline IA & $\mathrm{L}$ & 25 & Drug mngt & 2 & 4 & 3 & 8 & 1 & 1 & 3 & 4 & 9 & 10 & $\mathrm{H}$ \\
\hline FR & $\mathrm{P}$ & 25 & Prescription screening & 2 & 1 & 4 & 4 & 2 & 2 & 1 & 2 & 4 & 5 & M \\
\hline NI & $\mathrm{P}$ & 39 & Prescription screening & 2 & 2 & 4 & 6 & 2 & 2 & 2 & 4 & 7 & 8 & $\mathrm{H}$ \\
\hline SO & $\mathrm{L}$ & 32 & Prescription screening & 1 & 2 & 4 & 5 & 3 & 2 & 3 & 5 & 6 & 7 & M \\
\hline WL & $\mathrm{L}$ & 31 & Prescription screening & 3 & 3 & 4 & 8 & 2 & 2 & 2 & 4 & 9 & 11 & VH \\
\hline JL & $\mathrm{P}$ & 52 & Prescription screening & 2 & 1 & 1 & 1 & 2 & 1 & 2 & 2 & 1 & 2 & $\mathrm{~L}$ \\
\hline
\end{tabular}

*VH: Very high risk of MSDs, H: High risk of occurrence of MSDs, M: Risk medium occurrence of MSDs, L: Low risk of MSD occurrence, MSDs: Musculoskeletal disorders

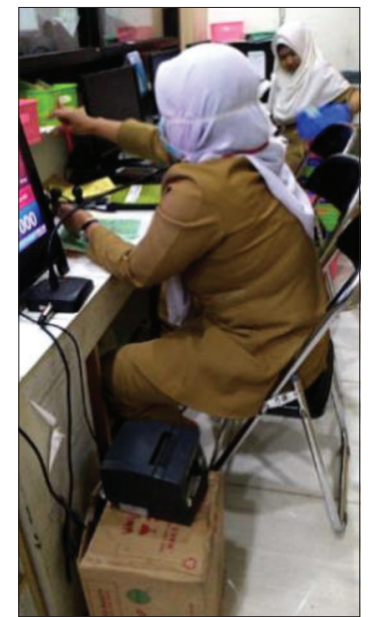

Fig. 4: Position of delivering drug information which have a high risk

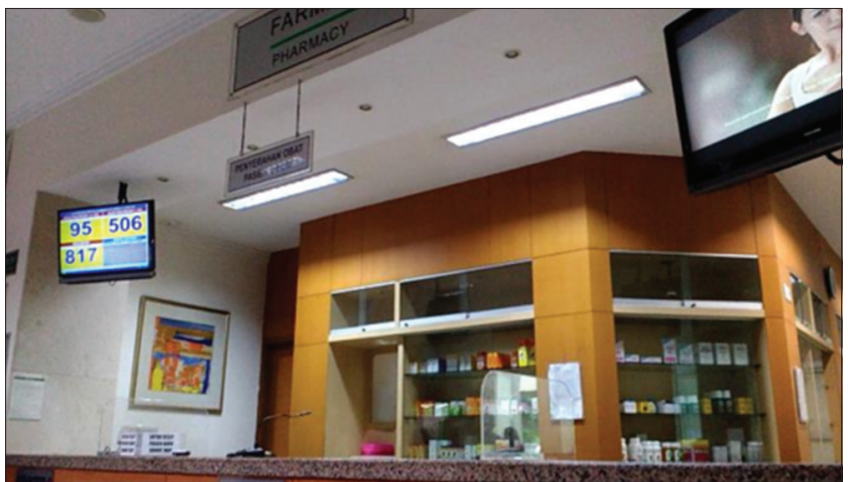

Fig. 5: Ideal drug information room

bottom area for walking access, in addition to prevent work accidents occurrence such as falling and stumble and to also meet the esthetics in the warehouse. An ergonomic guide for hospital pharmacies issued by OHSAS in 2004 explained ideal distance for taking goods, i.e. if item to 


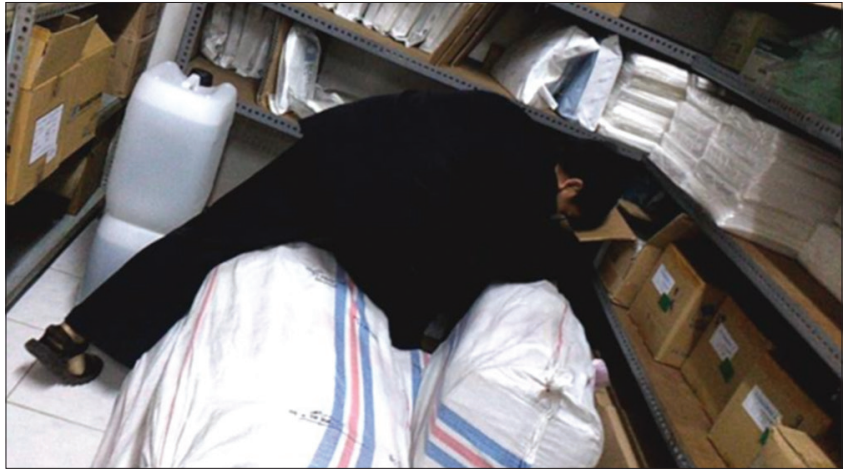

Fig. 6: Working position of the warehouse personnel that has a very high risk

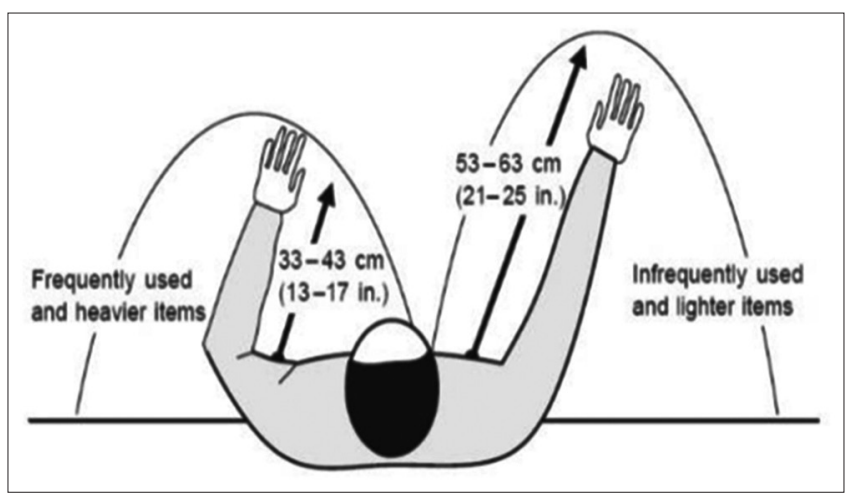

Fig. 7: Ideal distance for taking goods [13]

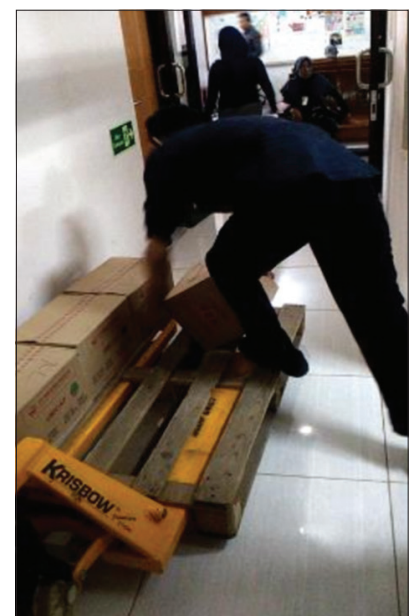

Fig. 8: A personnel transporting carrier with heavy load in a poor position

be taken is the heavy item ( $>5 \mathrm{~kg}$ ), then the distance between workers with the shelf is as far as $33-43 \mathrm{~cm}$, and if the item has a lighter weight, distance among workers with shelves is $53-63 \mathrm{~cm}$, as shown in Fig. 7. This can minimize spending muscle strength and body weight emphasis when taking heavy objects [12]

Fig. 8 shows a worker transported the box with heavy loads in poor position of the foot pedestal, back and how he placed the grip on the object.

According to the Ergonomic Guidelines for Manual Material Handling 2007 , the prevention of any work accident when hauling a load is transporting a load safely by getting or putting a safe handle, using the second hand, avoiding punctuation moment when lifting, placing the load close with the body, transporting without rotating the body, and

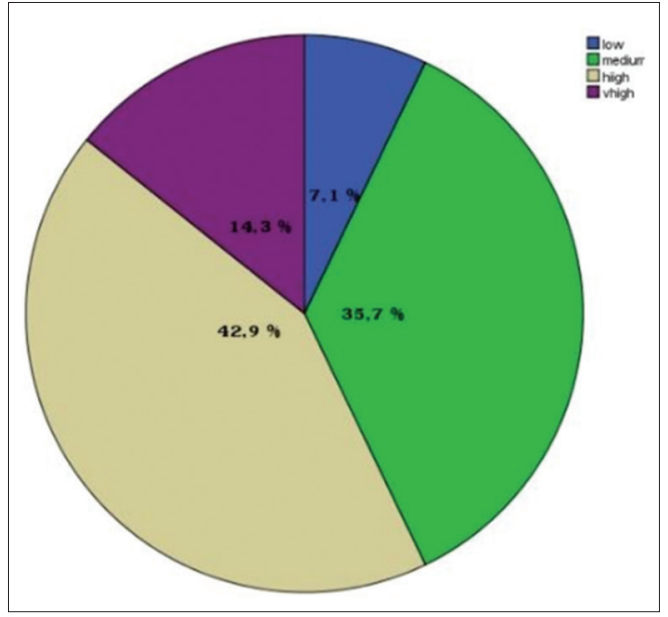

Fig. 9: Percentage of occurred musculoskeletal disorders and risk in hospital pharmacy

resting muscles for a moment before the next take [12].

This study had shown the results of the MSD potential risks on pharmaceutical workers in pharmacy installation as shown in Fig. 9.

Based on Fig. 9, it can be seen that as many as 7.1\% of pharmacy personnel at pharmacy installation had low risk of MSDs, 14.3\% have very high risk of MSDs, $35.7 \%$ have medium risks of MSDs, and $42.9 \%$ are at high risk of MSDs. High risk of MSDs had a large portion of other risks. This shows us that it is urgent need to take action as soon as possible in handling or preventing of MSDs in pharmacy personnel. The pharmacists in university, health services and community as preceptors supervising students in the field is an initiative for improving the quality of pharmaceutical services offered to society regarding with work safety[13].

\section{CONCLUSION}

Based on the results of the study, it can be concluded that high risks MSDs had a large portion of other risks. It had showed us that it is urgent need to take action as soon as possible in handling or preventing of MSDs in pharmacy personnel. High potential risks arisen were due to the presence of base factors that appeared during pharmaceutical activities including force, repetition, odd posture, static posture, and contacts that cause trauma which arise due to body position or posture during works, equipment work placement, pharmaceutical preparations placement, and working environment.

\section{REFERENCES}

1. Depkes RI. Health and Safety Management Guidelines at Hospital Kepmenkes RI No. 432/Menkes/SK/IV/2007. Jakarta: Depkes RI; 2007.

2. Depkes RI. Directorate of Community Pharmacy and Clinic DG of Pharmaceutical and Medical Devices of Ministry of Health. Health and Safety Guidelines at Hospital Pharmacy Installation. Jakarta: Depkes RI; 2006.

3. Depkes RI. Indonesian Law No. 36 Year 2009 About Health. Jakarta: Depkes RI; 2009.

4. Tarwaka. Basic Knowledge of Ergonomics and Applications In The Workplace. Solo: Harapan Press Solo; 2010.

5. Izzadirat H. Prevalence of musculoskeletal disorders and associated factors among adults living in Aq Qalaian rural, Iran. Int J Musculoskeletal Pain Prev 2016;1:55-9.

6. Aminian O, Alemohammad ZB, Sadeghniiat-Haghighi K. Musculoskeletal Disorders in Female Dentists and Pharmacists: A Cross Sectional Study. Acta Med Iran 2012;50(9).

7. Istighfaniar K, Mulyono. Evaluation of work posture and musculoskeletal complaints in pharmaceutical installation workers. Indonesian Journal of Occupational Safety and Health (IJOSH) 2016; 5(1):81-90.

8. Hignett S, McAtamney L. Rapid Entire Body Assessment (REBA). 
Applied. Ergonomics 2000;31:201-6.

9. Computer/Electronic Accommodations Program. The Workplace Ergonomics Reference Guide. $3^{\text {rd }}$ ed. Computer/Electronic Accommodations Program; 2016. Available From: http://www.cap.mil/ Documents/Workplace_Ergonomics_Reference_Guide.pdf.

10. Kristina SA, Wiedyaningsih C, Widyakusuma NN, Aditama $\mathrm{H}$. Extemporaneous compounding practice by pharmacists: A systematic review. Int J Pharm Pharm Sci 2017;9(2):42-46.

11. OHSAS. An Ergonomic Guide For Hospital Pharmacies. Vancouver:
OHSAS; 2014.Available from: http://www.phsa.ca/Documents/ Occupational-Health-Safety/GuideAnErgonomicGuidefor HospitalPharmacies.pdf.

12. Mendonça SAM, Meireles BL, Freitas EL, Oliveira DR. Pharmacy practices experiential programs in the context of clinical education. Int J Pharm Pharm Sci 2017;9(2):35-41

13. California Department of Industrial Relations. Ergonomic Guidelines for Manual Material Handling 2007. DHHS (NIOSH) Publication No. 2007-131; 2007. 